\title{
USE OF THE CORPORATE FORM FOR PUBLIC BENEFIT - REVITALISATION OF AUSTRALIAN CORPORATIONS LAW
}

\author{
ROSEMARY TEELE LANGFORD*
}

This article specifically addresses the theme of revitalisation of Australian law in the facilitation of purpose-based companies. It is the second of two articles on purpose-based governance in the charitable and for-profit spheres. Building on the first article, this article critically analyses relevant features of the Australian corporations law regime. It pays close attention to challenges relating to the application of directors' duties where companies have multiple purposes and to the drafting of appropriate constitutional provisions. In so doing it draws on insights from overseas jurisdictions that have enacted legislation to enable purpose-based companies.

\section{INTRODUCTION}

In recent times there have been movements in a number of Commonwealth jurisdictions to introduce companies which have as their aim (or one of their aims) the achievement of social or public benefit. Included within this category are social enterprise and shared value companies. Some jurisdictions have enacted legislation to enable specific corporate forms for such companies. In others the pressure is building for the introduction of such form. Debate also continues as to whether the traditional corporate form can be adapted to facilitate pursuit of purpose without tailored legislative amendments. These developments may be thought to constitute a paradigm shift given the prevalent association between the corporate form and profit maximisation. However, as demonstrated by this article, this is not the case. In fact these developments are evidence of revitalisation of the law in practical ways to meet new societal values and demands.

This article critically analyses the feasibility of purpose-based companies from the perspective of Australian corporations law. In an earlier article in this journal it was demonstrated that, despite the absence of special-purpose legislation, Australian companies can adopt purposes in their constitutions and that such

* Associate Professor, Melbourne Law School, University of Melbourne. This research was funded fully by the Australian Government through the Australian Research Council. My thanks to Cate Read and Miranda Webster for research assistance and to the anonymous reviewers for valuable comments. 
purposes shape directors' duties. ${ }^{1}$ It was also shown that Australian corporations law permits companies to pursue purposes other than (or in addition to) shareholder wealth maximisation. This second article provides extended detail on relevant aspects of the corporations law regime and focuses more closely on particular issues that arise in the facilitation of purpose-based companies. These include the application of directors' duties in the context of such companies, with particular focus on the application of the duty to act in good faith in the interests of the company where companies have multiple purposes. This in turn has relevance for the drafting of appropriate constitutional provisions. Other issues arise in relation to standing and enforcement, departure from purposes and signalling. The focus of analysis is on the for-profit corporate form given that it is uncontroversial that other corporate forms (such as companies limited by guarantee) can be used for charitable and not-for-profit purposes.

In this respect, experience from the United Kingdom ('UK') and United States ('US') can provide helpful insights in the revitalisation of Australian law. In particular, scholarly analysis of the issues arising from these overseas legislative regimes is invaluable in determining the application of directors' duties to purposebased companies and in framing appropriate constitutional provisions. Although changes to the law are not necessary to enable companies to adopt purposes, these lessons from other jurisdictions that have legislated to allow for special-purpose companies are therefore instructive in revitalising Australian law.

The structure of this article is as follows. Part II briefly outlines the movement towards social enterprises and other purpose-based company forms. Part III traces the development of the corporate form, with particular focus on for-profit companies and statutory directors' duties. It demonstrates the fact that statutory duties do not protect shareholders alone but also incorporate an element of public interest. Part IV outlines key features of special-purpose legislation in place in overseas jurisdictions and the important insights that can be gained from aspects of this legislation and from scholarly analysis of the issues that have arisen in connection with this legislation. Part V provides detailed critical analysis of the particular issues that arise in the application of directors' duties in the context of purpose-based companies. It gives special attention to the challenges that are thought to arise where companies adopt multiple purposes and the related issue of drafting of appropriate constitutional provisions. Part VI engages with aspects that are identified as problematic for purpose-based companies in the absence of express legislation. Part VII concludes.

This facilitation of purpose-based companies evinces both revitalisation of the law in response to practical developments, as well as revitalisation of legal authorities in areas where the progress of time has given rise to the need for reassessment of corporate law authorities and assumptions in response to the demand for purpose-based companies. 


\section{SOCIAL ENTERPRISE MOVEMENT}

A well-known form of purpose-based company is the social enterprise. Social enterprises have been defined as 'organisations with an economic, social, cultural or environmental mission consistent with a public or community benefit that trade to fulfil their mission'. ${ }^{2}$ Social enterprises may take a number of forms such as corporations limited by shares, corporations limited by guarantee, co-operatives, charitable corporations or not-for-profit associations. A core characteristic of social enterprises is 'the running of an enterprise to achieve an economic, social, cultural or environmental mission that benefits the public or a particular community ${ }^{3}{ }^{3}$ The Australian Charities and Not-for-profits Commission estimates that there are approximately 20,000 social enterprises in Australia that operate in local, national and international markets. ${ }^{4}$

Jurisdictions such as the UK, US and Canada have legislated to facilitate special-purpose entities to enable social enterprise. ${ }^{5}$ In jurisdictions such as Australia and New Zealand advocates are pushing for legislative reform to enable social enterprise companies and public benefit companies. For example, in Australia B Lab is seeking to have the Corporations Act 2001 (Cth) ('Corporations $\left.A c t^{\prime}\right)$ amended to facilitate benefit corporations. ${ }^{6}$ Key arguments for the

2 Strengthening for Purpose: Australian Charities and Not-For-Profits Commission Legislation Review 2018 (Report, 31 May 2018) 17 ('Strengthening for Purpose'), citing Jo Barraket et al, Finding Australia's Social Enterprise Sector (Final Report, June 2010) 4. See also Marina Nehme and Fiona Martin, 'Social Entrepreneurs: An Evaluation of the Pty Ltd Company from a Corporation's Law and Taxation Law Perspective' (2019) 93(2) Australian Law Journal 126, 129-30; Elizabeth Pollman, 'Social and Asocial Enterprise' in Benjamin Means and Joseph W Yockey (eds), The Cambridge Handbook of Social Enterprise Law (Cambridge University Press, 2018) 11; Carol Liao, 'Early Lessons in Social Enterprise Law' in Benjamin Means and Joseph W Yockey (eds), The Cambridge Handbook of Social Enterprise Law (Cambridge University Press, 2018) 101.

3 Justice Connect Not-For-Profit Law, 'Social Enterprise Guide: Legal Issues to Consider When Setting up a Social Enterprise' (Guide, July 2017) 5. One definition that is often referred to in Australia is the definition used by Social Traders, at 7, namely:

Social enterprises are organisations that:

- $\quad$ are led by an economic, social, cultural, or environmental mission consistent with a public or community benefit

- $\quad$ trade to fulfil their mission

- derive a substantial portion of their income from trade, and

- reinvest the majority of their profit/surplus in the fulfilment of their mission.

For further discussion see Nina Boeger, 'Shaping Corporate Reform: Social Enterprise, Cooperatives, and Mission-Led and Employee-Owned Business' in Benjamin Means and Joseph W Yockey (eds), The Cambridge Handbook of Social Enterprise Law (Cambridge University Press, 2018) 123.

4 See Strengthening for Purpose (n 2) 17, citing Department of Social Services (Cth), A New System for Better Employment and Social Outcomes: Report of the Reference Group on Welfare Reform to the Minister for Social Services (Report, February 2015) 172. See also Alice Klettner, 'Finding the Balance between Profit and Purpose: Should Australia Create a Legal Structure for Social Enterprise?' (2019) 47(5) Australian Business Law Review 335.

5 See below Part IV for more detail.

6 See B Lab Australia and New Zealand, 'Social Impact Investing Discussion Paper' (Discussion Paper, February 2017) Attachment C <https://treasury.gov.au/sites/default/files/2019-03/c2017-183167-BLab.pdf $>$. 
introduction of the legislation are the uncertainty faced by directors as to whether they are properly complying with their duties if they favour stakeholders and whether they may be open to action for breach of duty if they do not achieve the company's purposes. ${ }^{7}$

Momentum is also building in New Zealand for the introduction of a specialpurpose social enterprise model, as advocated in Structuring for Impact: Evolving Legal Structures for Business in New Zealand ('Impact Initiative Report'). ${ }^{8}$ The particular issues articulated in this report are the ability of social enterprises to convey and protect their mission; access to funding; segmentation of the for-profit business and charity as two parts of the economy; 9 and the fact that "current legal structures struggle to accommodate the fundamental differences in operation, motivating values, and the different types of capital when a trading enterprise is mission-led'. ${ }^{10}$ This report proposes legal facilitation of impact companies which are a for-profit structure that prioritise impact and have an impact mandate and impact reporting. ${ }^{11}$ Each impact company would be required to prepare and publish an annual report that outlines how it has performed in achieving its impact mission. The report notes that further work needs to be done on the application of directors' duties in the context of impact companies. ${ }^{12}$ In this respect a critical analysis of directors' duties is undertaken in Part V below.

\section{DEVELOPMENT OF CORPORATIONS LAW}

The use of companies to promote public or community benefits is unsurprising given the origins of the corporate form. This Part provides a brief overview of salient developments in the history of company law. In fact the history and development of Australian corporations law evinces malleability and constant revitalisation of the corporate form, as well as use of that form for public and social purposes. The ability of for-profit companies to pursue public benefit is therefore a natural evolution and revitalisation of the corporate form rather than a paradigm change. This Part also outlines the increasing relevance of stakeholder interests and the public facet of the statutory directors' duties in the Corporations Act.

\section{A Origins of the Corporate Form}

The corporate form was not originally associated with profit maximisation. The original use of the corporate form was 'for ecclesiastical, municipal,

Ibid Attachment D, 2-3 [2.13]-[2.15], 5 [4.3], 6 [4.8].

8 Jane Horan et al, Structuring for Impact: Evolving Legal Structures for Business in New Zealand (Report, 2019) ('Impact Initiative Report').

9 Ibid 5, 10.

10 See especially ibid 13 . See also Klettner (n 4).

11 By 'impact mandate' the report envisages that each company 'would be required to adopt a constitution including a statement that sets out the impact the entity is seeking to achieve and the prioritisation of impact alongside distribution of profits': Impact Initiative Report (n 8) 31. 
educational, and other public or semipublic purposes'. ${ }^{13}$ Corporations sole arose in response to property being left to the church and the need to create an artificial person so as to separate between the managerial role of bishops (or other church officials) in relation to church land and their private capacities. ${ }^{14}$ This enabled church land to pass to successor church officials. Corporations aggregate were used to endow legal existence on organised groups such as boroughs and colleges in order to facilitate that group holding property and engaging in dealings as an entity distinct from the individual members. ${ }^{15}$

The corporate form was also used for the purposes of obtaining a trading monopoly (generally in another jurisdictions). ${ }^{16}$ This was in turn linked to public finance in a number of ways in that companies made payments to the Crown in return for the monopolies, paid considerable amounts of custom and also took upon themselves expenses that would otherwise have been carried by the state. ${ }^{17}$ Harris describes how the improvement of the navigability of rivers was financed by way of joint stock companies. ${ }^{18}$ Companies were also used to enable infrastructure projects such as railways - the corporate form allowed the aggregation of the funds of multiple investors. ${ }^{19}$

\section{B Types of Company}

The malleability of the corporate form is also demonstrated by the array of types of company and the uses to which they can be put. Australian corporations law permits incorporation of different types of companies, including companies limited by shares (which can be public or private), companies limited by guarantee and no liability companies (which are exclusively for mining). Companies limited by guarantee cannot distribute profit to members. Such companies are particularly suitable for not-for-profit and charitable ventures.

\section{For-Profit Companies}

The focus of the debate on purpose-based companies concerns for-profit companies, viz companies that can distribute profit to members. ${ }^{20}$ Over time this corporate form has become synonymous with shareholder primacy and profit

13 Ron Harris, Industrializing English Law (Cambridge University Press, 2000) 39. See also Rob McQueen, A Social History of Company Law: Great Britain and the Australian Colonies 1854-1920 (Ashgate, 2009) 1.

14 Chief Justice TF Bathurst, 'The Historical Development of Corporations Law' (2013) 37(3) Australian Bar Review 217, 218.

15 Ibid 218-19. See also Armand Budington DuBois, The English Business Company After the Bubble Act 1720-1800 (Octagon Books, 1971) 1.

16 McQueen (n 13) 35.

17 See Harris (n 13) 39-42.

18 See ibid 91-2.

19 See John D Turner, 'The Development of English Company Law before 1900' (QUCEH Working Paper No 2017-01, Centre for Economic History, Queen's University Belfast, January 2017).

20 A 'for-profit company' is generally understood to be a company that can distribute profits to shareholders. Note also other forms available for the formation and conduct of associations, namely incorporated associations, co-operatives and unincorporated associations. 
maximisation so that it has been assumed that directors are bound to maximise profit. ${ }^{21}$ However, the fact that directors are ultimately accountable to shareholders ${ }^{22}$ does not necessarily mean that short-term profit maximisation is required of them. ${ }^{23}$ It is open to shareholders to choose purposes other than, or in addition to, profit. A number of the problems that have been identified in relation to the shareholder primacy theory are in fact arguably more correctly caused by the adoption of a short-term focus. This is in turn caused by a number of extralegal factors (such as short-term reporting requirements and remuneration structures). As pointed out by Commissioner Hayne in the Banking Royal Commission Final Report:

The longer the period of reference, the more likely it is that the interests of shareholders, customers, employees and all associated with any corporation will be seen as converging on the corporation's continued long-term financial advantage. And long-term financial advantage will more likely follow if the entity conducts its business according to proper standards, treats its employees well and seeks to provide financial results to shareholders that, in the long run, are better than other investments of broadly similar risk. ${ }^{24}$

Moreover, courts have recognised that companies have interests in addition to those of shareholders. ${ }^{25}$

21 As concerns shareholder primacy, see Milton Friedman, 'The Social Responsibility of Business Is to Increase Its Profits', The New York Times Magazine (New York, 13 September 1970) 33; AA Berle Jr, 'Corporate Powers as Powers in Trust' (1931) 44(7) Harvard Law Review 1049; Jonathan R Macey, 'An Economic Analysis of the Various Rationales for Making Shareholders the Exclusive Beneficiaries of Corporate Fiduciary Duties' (1991) 21(1) Stetson Law Review 23; Stephen M Bainbridge, 'In Defense of the Shareholder Maximisation Norm: A Reply to Professor Green' (1993) 50(4) Washington and Lee Law Review 1423; Bernard Black and Reinier Kraakman, 'A Self-Enforcing Model of Corporate Law' (1996) 109(8) Harvard Law Review 1911. For challenges to this model, see E Merrick Dodd Jr, 'For Whom Are Corporate Managers Trustees?' (1932) 45(7) Harvard Law Review 1145; E Merrick Dodd Jr, 'Is Effective Enforcement of the Fiduciary Duties of Corporate Managers Practicable?' (1935) 2(2) University of Chicago Law Review 194; R Edward Freeman, Strategic Management: A Stakeholder Approach (Pitman, 1984); Margaret M Blair and Lynn A Stout, 'A Team Production Theory of Corporate Law' (1999) 85(2) Virginia Law Review 247; Margaret M Blair and Lynn A Stout, 'Director Accountability and the Mediating Role of the Corporate Board' (2001) 79(2) Washington University Law Quarterly 403; Kent Greenfield, The Failure of Corporate Law: Fundamental Flaws and Progressive Possibilities (University of Chicago Press, 2006).

22 See Langford, 'Purpose-Based Governance' (n 1).

23 For detailed analysis, see ibid.

24 Royal Commission into Misconduct in the Banking, Superannuation and Financial Services Industry (Final Report, February 2019) vol 1, 401-2.

25 See, eg, Pilmer v Duke Group Ltd (in liq) (2001) 207 CLR 165, 178-9 [18] (McHugh, Gummow, Hayne and Callinan JJ); Australian Securities and Investments Commission v Cassimatis [No 8] (2016) 336 ALR 209, 301-2 [482]-[483] (Edelman J), upheld on appeal in Cassimatis v Australian Securities and Investments Commission (2020) 376 ALR 261. Note also the early cases of Hutton v West Cork Railway Co (1883) 23 Ch D 654; Re George Newman \& Co [1895] 1 Ch 674 which, as noted by Austin and Ramsay, illustrate the fact that 'management may implement a policy of enlightened self-interest on the part of the company but may not be generous with company resources when there is no prospect of commercial advantage to the company': see LexisNexis, Ford, Austin \& Ramsay's Principles of Corporations Law (online at February 2020) [8.130]. See below Part III(E) for further discussion. 


\section{Stakeholder Interests}

Commissioner Hayne's comments also highlight the revitalisation of corporations law that has occurred in the gradual and increasing requirement that directors have regard to the interests of stakeholders. Such stakeholders include creditors, customers, the community and the environment. This is achieved through a number of different mechanisms. For example, legislation is imposed on companies in relation to matters such as occupational health and safety, environmental protection and labour law. In addition, directors' core duties to act with care, skill and diligence and in good faith in the interests of the company are increasingly requiring directors to have regard to stakeholder interests. ${ }^{26}$

One recurring issue is the ability of, or need for, directors to consider and potentially take positive action in relation to climate change in the discharge of their duties. ${ }^{27}$ This has been highlighted in recent months by Hayne ${ }^{28}$ and Fink. ${ }^{29}$ Hayne has stated that '[i]n Australia, a director acting in the best interests of the company must take account of, and the board must report publicly on, climaterelated risks and issues relevant to the entity'. ${ }^{30}$ These comments highlight the importance of directors considering climate-related factors in their decisionmaking and the fact that these factors are becoming financial factors. At the same time, the decisions that directors make and the factors they consider need to be viewed through the lens of the particular company's interests. Although it is debatable whether directors have a separate and direct duty as concerns climate change, there is no doubt that directors need to actively consider climate change issues in discharging their duties to act in good faith in the interests of the company and with care, skill and diligence. This is particularly the case where there is financial impact.

Moreover, the financial interests of companies and their shareholders are changing to include stakeholder interests so that it is in the interests of the company and shareholders to consider, and even protect, stakeholder interests in many circumstances. In addition, given the importance of a company's reputation, it will rarely be in the interests of a company (and therefore derivatively of its shareholders) to ignore stakeholder interests and concerns. There is also increased

26 For outline, see, eg, Australian Securities and Investments Commission v Cassimatis [No 8] (2016) 336 ALR 209, 301-2 [482]-[485] (Edelman J); Noel Hutley and Sebastian Hartford Davis, 'Climate Change and Directors' Duties' (Supplementary Memorandum of Opinion, Centre for Policy Development, 26 March 2019); Rosemary Teele Langford, 'Social Licence to Operate and Directors' Duties: Is There a Need for Change?’ (2019) 37(3) Company and Securities Law Journal 200.

27 See further Australian Securities and Investments Commission, Climate Risk Disclosure by Australia's Listed Companies (Report No 593, September 2018); Australian Prudential Regulation Authority, 'Climate Change: Awareness to Action' (Information Paper, 20 March 2019).

28 See Kenneth Hayne (Speech, Business Roundtable on Climate and Sustainability, Centre for Policy Development, 21 November 2019) ('Centre for Policy Development Speech').

29 See Larry Fink, 'A Fundamental Reshaping of Finance’ BlackRock (Letter, January 2020) $<$ https://www.blackrock.com/corporate/investor-relations/larry-fink-ceo-letter>.

30 See Hayne, 'Centre for Policy Development Speech' (n 28) 2. 
recognition of the importance of reputation and the value placed by investors and the community on socially responsible business practices. ${ }^{31}$

\section{E Statutory Duties}

It is also notable that the duty in section 181 of the Corporations Act and equivalent general law duty require directors to act in the interests of the company. The company's interests are therefore the focus of this duty. In Australia the statutory directors' duties in the Corporations Act protect a number of stakeholders (rather than just shareholders), incorporating a public interest aspect. ${ }^{32}$ Furthermore, unlike jurisdictions such as the UK, these statutory directors' duties are not expressed to be owed to the company, and courts have recognised that these duties do not just protect shareholders - they protect the public as well. ${ }^{33}$ This is reflected in the fact that there is public enforcement of the duties by a regulator and that civil penalty consequences (including pecuniary penalty and disqualification) may flow from breach. ${ }^{34}$ One important upshot of the public nature of these duties is that shareholders cannot ratify breach of statutory duties. ${ }^{35}$

These aspects of the statutory directors' duties regime were reaffirmed very recently by the Full Court of the Federal Court in Cassimatis v Australian Securities and Investments Commission in which the majority held that shareholders who are also directors could not approve their own conduct in contravention of section 180 or release themselves from such contravention. ${ }^{36} \mathrm{In}$ so doing the judges recognised the public aspects of the statutory directors' duties regime. ${ }^{37}$ In terms of purpose-based companies, this has been seen to raise the issue

31 See, eg, Australian Securities and Investments Commission v Cassimatis [No 8] (2016) 336 ALR 209, 301-2 [482]-[483] (Edelman J); ASX Corporate Governance Council, 'Corporate Governance Principles and Recommendations' (Principles and Recommendations $4^{\text {th }}$ ed, February 2019) $16,18,29-30$ (commentary to Recommendations 3.1, 3.4, 8.1).

32 For discussion, see, eg, Jason Harris, Anil Hargovan and Janet Austin, 'Shareholder Primacy Revisited: Does the Public Interest Have Any Role in Statutory Duties?' (2008) 26(6) Company and Securities Law Journal 355; Michelle Welsh, 'Realising the Public Potential of Corporate Law: Twenty Years of Civil Penalty Enforcement in Australia' (2014) 42(1) Federal Law Review 217.

33 See, eg, Forge v Australian Securities and Investments Commission (2004) 213 ALR 574, 654-5 [381] (McColl JA); Angas Law Services Pty Ltd (in liq) v Carabelas (2005) 226 CLR 507, 523 [32] (Gleeson CJ and Heydon J); Australian Securities and Investments Commission v Australian Investors Forum Pty Ltd [No 2] (2005) 53 ACSR 305, 315 [33]-[34] (Palmer J); International Swimwear Logistics Ltd v Australian Swimwear Company Pty Ltd [2011] NSWSC 488 [106], [109] (Ward J).

34 See, eg, Australian Securities and Investments Commission v Cassimatis [No 8] (2016) 336 ALR 209, 296 [453]-[455] (Edelman J), upheld on appeal in Cassimatis v Australian Securities and Investments Commission (2020) 376 ALR 261; Dimity Kingsford Smith, 'Australian Director's Duties: Are They Public Duties?' (Conference Paper, Supreme Court of New South Wales Corporate and Commercial Law Conference, 2018).

35 See, eg, Forge v Australian Securities and Investments Commission (2004) 213 ALR 574, 654-5 [381] (McColl JA); Angas Law Services Pty Ltd (in liq) v Carabelas (2005) 226 CLR 507, 523 [32] (Gleeson CJ and Heydon J); Australian Securities and Investments Commission v Australian Investors Forum Pty Ltd [No 2] (2005) 53 ACSR 305, 315 [35] (Palmer J).

36 See Cassimatis v Australian Securities and Investments Commission (2020) 376 ALR 261, 305 [196] (Greenwood J), 369 [472] (Thawley J).

37 See, eg, ibid 274 [27], 293-8 [131]-[157] (Greenwood J), 314 [240] (Rares J). In the first instance decision, which was upheld in this appeal, Edelman $\mathrm{J}$ found that a contravention of $\mathrm{s} 180$ can be both a 
of potential exposure of directors of such companies to liability for breach of statutory duty where members have authorised pursuit of particular purposes. This issue is critically analysed in Part V(B) below.

\section{F Legislative Change}

Despite a number of inquiries and reform proposals, Australia has not seen legislative reform either to introduce legislation to facilitate purpose-based companies or to amend the duty to act in good faith in the interests of the company to allow or require directors to have regard to, or promote, the interests of stakeholders. The key reasons why the duty in section 181 has not been amended are accountability and enforceability - there have been concerns that such a change 'could either subject directors to conflicting or competing fiduciary duties and obligations of accountability or in effect free them of any such ... obligations' ${ }^{38}$ Additional concerns are

how to identify relevant classes of stakeholders, how to determine which stakeholders should have standing to enforce the duties, whether courts might become involved in making commercial decisions if called on to balance or weigh up competing stakeholder interests, and whether criminal or civil enforcement of directors' duties would be compromised if directors could refer to a range of competing or conflicting stakeholder interests in defending claims of breach of duty. ${ }^{39}$

Although Australia has not legislated to amend the duty to act in good faith in the interests of the company in section 181 or to introduce legislation to facilitate purpose-based companies, the revitalisation of Australian corporate law propounded in this and the previous article is a natural progression given the origins of the corporate form and the gradual recognition of stakeholder interests in determining the interests of the company.

\section{EXPRESS LEGISLATION}

More recently some jurisdictions have introduced special-purpose corporate vehicles. A number of different models are observable. This Part briefly outlines pertinent features of some of these models for the purposes of further analysis. Insights from these legislative models are instructive in the revitalisation of Australian law to facilitate, and promote the success of, purpose-based companies, which this article argues can be achieved without express legislation.

private and public wrong: Australian Securities and Investments Commission v Cassimatis [No 8] (2016) 336 ALR 209, 296-7 [455]-[457].

38 See, eg, Corporations and Markets Advisory Committee, The Social Responsibility of Corporations (Report, December 2006) 97 [3.8.1].

39 Ibid. The Corporations and Markets Advisory Committee did, however, note that a company could choose (via a shareholder resolution) 'to hold itself to a particular approach to the conduct of its business by adopting some form of "social responsibility" charter in its constitution': at ibid 111 [3.12]. 


\section{A United States}

Different types of purpose-based company models exist in the US. These legislative regimes provide an exemplar of legislative reforms that could be adopted in Australia were special-purpose legislation to be adopted. ${ }^{40}$ Even more relevant, however, are the problems and uncertainties that have been identified in the application of these legislative models.

\section{Overview of Types of Special-Purpose Companies}

US benefit corporations must have a binding corporate purpose in the constitution requiring the company to create general public benefit, defined as '[a] material positive impact on society and the environment, taken as a whole, from the business and operations of a benefit corporation assessed taking into account the impacts of the benefit corporation as reported against a third-party standard' ${ }^{41}$ Such companies can also articulate a specific public benefit. Directors are required to consider the interests of a wide range of stakeholders in addition to the interests of shareholders. They are not, however, required to prioritise any interest. Regular public reporting of overall social and environmental performance is mandated. The legislation often facilitates 'benefit enforcement proceedings', which enable action to be brought against the company in certain circumstances. ${ }^{42}$

By contrast, Delaware benefit corporation statutes do not mandate a general public benefit purpose, allowing such corporations to decide what role and priority their public benefit purpose(s) will have as compared to other purposes and interests. Directors of such corporations balance shareholders' financial interests with the interests of those materially affected by the company's conduct and with the entity's public benefit purpose. ${ }^{43}$ Other models include the low-profit limited liability company ('L3C') $)^{44}$ and state-specific legal hybrid forms.

\section{Insights to be Gained}

Current US models have been criticised as weakening accountability, in particular due to the problems caused by divided loyalty due to directors needing to pursue multiple purposes. This raises the issue of whether directors of Australian purpose-based companies are similarly less accountable due to the potential tension between multiple purposes. This is critically analysed in Part V(B) below.

40 For outlines of US models, see Dana Brakman Reiser and Steven A Dean, 'The Social Enterprise Life Cycle' in Benjamin Means and Joseph W Yockey (eds), The Cambridge Handbook of Social Enterprise Law (Cambridge University Press, 2018) 223; Liao (n 2); Klettner (n 4) 341-2. For another model, see B Lab Australia and New Zealand (n 6).

41 See B Lab, Model Benefit Corporation Legislation §§ 102, 201(a) $<$ https://benefitcorp.net/sites/default/files/Model\%20benefit\%20corp\%20legislation\%20_4_17_17.pdf> ('B Lab Model Legislation'). For discussion, see Dana Brakman Reiser and Steven A Dean, Social Enterprise Law: Trust, Public Benefit, and Capital Markets (Oxford University Press, 2017) 53 ('Social Enterprise Law').

$42 \quad$ Reiser and Dean, Social Enterprise Law (n 41) 57.

43 Ibid 65-6; Lyman Johnson, 'Managerial Duties in Social Enterprise: The Public Benefit Corporation' in Benjamin Means and Joseph W Yockey (eds), The Cambridge Handbook of Social Enterprise Law (Cambridge University Press, 2018) 341, 348-9. 
The US and Delaware public benefit corporation statutes have also been criticised due to problems with enforcement and accountability. Particular concerns surround the nature of benefit enforcement proceedings and the wide discretion given to directors. Reiser and Dean object that standing is only conferred on directors, shareholders (often only if meeting certain ownership thresholds) and stakeholders identified by an individual benefit corporation in its charter ${ }^{45}$ They are also critical of the fact that successful proceedings 'will result at most in a trenchant court order to toe the line', pointing out that benefit corporation statutes 'preclude imposition of monetary liability on defendant companies and fiduciaries alike' ${ }^{46}$ In their view standing should be conferred upon 'a pool of enforcers, including government officials, private certifying bodies, investors and other stakeholders, and even ... competitors' ${ }^{47}$ The weaknesses in the US models are informative considerations in the framing of any special-purpose legislation in Australia. These issues are highlighted in Part VI below.

\section{B United Kingdom}

The UK permits several different types of special-purpose company, including the community interest company. ${ }^{48}$

\section{Community Interest Companies}

In the UK the Companies (Audit, Investigations and Community Enterprise) Act 2004 (UK) introduced community interest companies (or 'CICs'). Such entities are subject to a 'community interest test', determined based on whether 'a reasonable person might consider that [the entity's] activities [or proposed activities] are being carried on for the benefit of the community'. ${ }^{49}$ CICs must report annually on their community interest achievements and their efforts to include non-shareholder stakeholders in their governance process. ${ }^{50}$ A key feature of CICs is the asset lock, which prevents the entity from disposing of assets for less than fair market value consideration, other than in pursuing community benefits or in a transfer to a charity or another CIC. CIC directors have an overriding primary duty to advance the community purpose. The CIC Regulator has significant powers of investigation and intervention and can bring claims relating to directors' compliance, appoint and remove directors, act to protect a CIC's assets and dissolve a CIC. ${ }^{51}$ In fact the success of CICs has been attributed

\footnotetext{
45 Reiser and Dean, Social Enterprise Law (n 41) 57.

46 Ibid 57.

47 Ibid 35.

48 The UK also permits incorporation of charitable incorporated organisations: see, eg, Charities Act 2011 (UK) pt 11, and community benefit societies: see, eg, Co-operative and Community Benefit Societies Act 2014 (UK).

49 Companies (Audit, Investigations and Community Enterprises) Act 2004 (UK) s 35(2).

$50 \quad$ Ibid $\mathrm{s} 34$.

51 Ibid ss 42 ('investigation'), 44 ('civil proceedings'), 45 ('appointment of director'), 46 ('removal of director'), 48 ('property'), 51 ('dissolution and striking off').
} 
partly to the involvement of the regulator. ${ }^{52}$ In addition to the CIC legislation, the Companies Act 2006 (UK) ('Companies Act') is facilitative of purpose-based companies.

\section{Insights to be Gained}

One aspect of the CIC model that has been criticised is the asset lock, on the basis that it may deter investors and limit the growth of purpose-based company sectors. ${ }^{53}$ More notable, however, is jurisprudence surrounding the statutory duty to act in good faith in the interests of the company in section 172 of the Companies Act and, in particular, consideration of multiple purposes. UK jurisprudence is particularly instructive given the common origins of, and continued fertilisation between, the UK and Australian company law systems.

\section{(a) Section 172(2)}

Section 172(2) of the Companies Act allows companies to adopt a purpose other than the benefit of its members, thus effectively enabling a public benefit purpose. Section 172(2) provides:

Where and to the extent that the purposes of the company consist of or include purposes other than the benefit of its members, subsection (1) has effect as if the reference to promoting the success of the company for the benefit of its members were to achieving those purposes. ${ }^{54}$

The Explanatory Notes to the Companies Act refer to altruistic (or partly altruistic) companies but note that it is possible for any company to have objectives that are unselfish and are paramount over the members' own interests. The Notes also state that it is a matter of good faith judgment of the directors as to what the company's purposes are. ${ }^{55}$

Section 172(2) builds on section 172(1), which codifies the core duty to act in good faith in the interests of the company to require directors to act in the way they consider, 'in good faith, would be most likely to promote the success of the company for the benefit of its members as a whole and in so doing to have regard' to a number of factors ${ }^{56}$ Ostensibly a more stakeholder-oriented model, this section arguably actually espouses shareholder primacy more clearly than the statutory equivalent in section 181 of the Corporations Act. This is because the

52 See Liao (n 2) 118.

53 See Impact Initiative Report (n 8) 32; Boeger (n 3) 128.

54 Section 171 of the Companies Act 2006 (UK) requires directors to act in accordance with the company's constitution. Paragraph 317 of the Explanatory Notes, Companies Act 2006 (UK) (after noting that a company's constitution may set out the company's purposes) states: 'It is very important that directors understand the purposes of the company, so that they are able to comply with their duty to promote the success of the company in section 172 '.

55 See Explanatory Notes, Companies Act 2006 (UK) [330].

56 These are,

amongst other matters ... (a) the likely consequences of any decision in the long term, (b) the interests of the company's employees, (c) the need to foster the company's business relationships with suppliers, customers and others, (d) the impact of the company's operations on the community and the environment, (e) the desirability of the company maintaining a reputation for high standards of business conduct, and (f) the need to act fairly as between members of the company. 
bottom line of section 172 is the benefit of the members as a whole whereas the bottom line of section 181 is the interests of the company. In addition, despite this changed wording, courts have interpreted the statutory duty in section 172 in line with its general law predecessor. ${ }^{57}$ In fact, due to concern that section 172 was having a limited impact on the way in which directors approach their duties or on the way in which companies approach reporting, ${ }^{58}$ additional reporting obligations have now been introduced. Provisions recently inserted into the Companies Act require additional disclosure of UK companies of significant size in relation to how directors have had regard to, and engaged with, stakeholders. ${ }^{59}$

\section{(b) Balancing}

The key reason for drawing attention to section 172(2) is that there has been helpful jurisprudence associated with section 172(2) concerning the issue of multiple purposes. It will be seen in Part V below that this has been raised as a potential problem in the application of directors' duties in the context of purposebased companies.

The Explanatory Notes to the Companies Act address the issue of the potential tension or balancing between different purposes. The Explanatory Notes to section 172(2) state that, where the company is 'partially for the benefit of its members and partly for other purposes, the extent to which those other purposes apply in place of the benefit of the members' is a matter for the good faith judgment of the directors. $^{60}$

Helpful guidance in this respect can be gained from the case of Stimpson $v$ Southern Landlords' Association. ${ }^{61}$ The relevant company was a non-profit company (limited by guarantee) which had purposes, some of which related to benefit of the members and some of which did not. The context was a derivative action under section 261 of the Companies Act, in relation to which the court had to decide whether a hypothetical director acting in accordance with section 172 of the Act would not seek to continue the claim. Judge Pelling QC (sitting as a judge of the High Court) thought that section 172(2) required a director to act in a way that they considered in good faith would most likely promote the success of the company for the benefit of its members as a whole whilst at the same time achieving its other purposes. His Honour then said: 'Where there is a conflict between promoting the success of the company for the benefit of its members and

57 See, eg, Re Southern Counties Fresh Foods Ltd [2008] EWHC 2810 (Ch), [52] (Warren J); West Coast Capital (Lios) Ltd [2008] CSOH 72, [21] (Lord Glennie); Madoff Securities International Ltd (in liq) $v$ Raven [2013] EWHC 3147 (Comm), [188]-[190] (Popplewell J).

58 See, eg, Department for Business, Energy and Industrial Strategy, Corporate Governance Reform (Green Paper, November 2016); Andrew Keay and Taskin Iqbal, 'The Impact of Enlightened Shareholder Value' [2019] (4) Journal of Business Law 304; Irene-Marie Esser, Iain MacNeil and Katarzyna ChalaczkiewiczLadna, 'Engaging Stakeholders in Corporate Decision-Making through Strategic Reporting: An Empirical Study of FTSE 100 Companies' (2018) 29(5) European Business Law Review 729.

59 See Companies Act 2006 (UK) ss 414CZA, 426B, 414C(2).

60 Explanatory Notes, Companies Act 2006 (UK) [330].

61 [2009] EWHC 2072 (Ch). 
the achievement of the other objectives, a balancing exercise will be required'. ${ }^{62}$ Where a company adopts multiple purposes (but the relative priority between those purposes is not specified) this case is therefore authority that directors should balance the relevant purposes. This jurisprudence, which addresses the perceived problem of divided loyalty, is helpful in the application of the duty to act in good faith in the interests of the company to Australian purpose-based companies, as outlined in Part V(B) below.

\section{DIRECTORS' DUTIES}

One of the key challenges in adapting the corporate form for use by purposebased companies is moulding directors' duties. This is where revitalisation, and detailed attention to revitalisation, are particularly needed. This Part takes up that challenge and demonstrates that directors' duties can indeed be adapted for purpose-based companies and that there are different options available to founders of such companies.

This moulding effects a revitalisation of the law in order to adapt it to practical developments and demands. Such revitalisation is a common strand in the development of directors' duties. Over time these duties have been developed and remoulded to respond to societal needs and changes. For example, the standard imposed under the duty of care has steadily increased, particularly as concerns the financial aspects of a company's business. ${ }^{63}$ As mentioned above, the duty to act in good faith in the interests of the company has gradually and increasingly incorporated consideration of stakeholder interests. Specific statutory duties have been introduced relating to related party transactions and insolvent trading. ${ }^{64}$

An earlier article in this Issue demonstrated that Australian law allows forprofit companies to adopt purposes in addition to shareholder profit and that the law of directors' duties adapts to such adoption. ${ }^{65}$ Articulation of a company's purposes in the constitution is the conduit for effecting purpose-based companies. That article paid particular attention to the duties of persons who govern charitable entities. This Part engages in detailed critical analysis of some particular issues that arise in the application of directors' duties to purpose-based companies in the corporate sphere. As mentioned above, lessons can be learnt from scholarship surrounding special-purpose legislation in overseas jurisdictions. A key concern expressed in relation to purpose-based company regimes concerns accountability of directors, and, in particular, potential tension between multiple purposes.

The core duties traditionally imposed on directors of for-profit companies are the duty of care, skill and diligence, the duty to act in good faith in the interests of

62 Ibid [26]. However, where some objects are in the minority or do not play a significant role in the activities of the company, the effect of s 172(2) may be less significant, as was found in that case: see ibid [27].

63 See, eg, Australian Securities and Investments Commission v Healey (2011) 196 FCR 291.

64 Corporations Act 2001 (Cth) ch 2E, s 588G ('Corporations Act').

65 See Langford, 'Purpose-Based Governance' (n 1). 
the company, the duty to act for proper purposes and duties to avoid unauthorised conflicts and profits.

\section{A Duty of Care, Skill and Diligence}

The duty of care, skill and diligence requires care, skill and diligence of directors in the performance of their functions. Section 180 of the Corporations Act (which applies in addition to the equivalent general law duty ${ }^{66}$ provides:

(1) A director or other officer of a corporation must exercise their powers and discharge their duties with the degree of care and diligence that a reasonable person would exercise if they:

(a) were a director or officer of a corporation in the corporation's circumstances; and

(b) occupied the office held by, and had the same responsibilities within the corporation as, the director or officer.

The duty of care incorporates objective and subjective elements - the test is objective but incorporates subjective considerations in taking account of the company's circumstances and the director or officer's position or responsibilities within the company. Factors included in a consideration of the company's circumstances for the purposes of section 180(1) include the type of company and the provisions of its constitution. ${ }^{67}$ The application of this duty to directors of purpose-based companies is straightforward. When applied to directors of purpose-based companies, regard would be had to the fact that the company was purpose-based as well as to the company's specific purposes and size. ${ }^{68}$

A question arises as to whether directors of purpose-based companies could be liable for breach of the duty of care if the company does not achieve its stated purposes. In this respect, the duty requires care, skill and diligence of directors of purpose-based companies in exercising their functions as directors and thus in seeking to achieve those purposes, but it does not necessarily require attainment of those purposes. For example, courts have held that

[s]ection 180(1) does not seek to punish the mere making of mistakes or errors of judgment. Making mistakes does not by itself demonstrate lack of due care and diligence. ... Directors and officers of corporations are expected to take calculated commercial risks. A company run on the basis that no risks were ever taken would

66 See Corporations Act s 185.

67 See, eg, Australian Securities and Investments Commission v Maxwell (2006) 59 ACSR 373, 397 [100] (Brereton J); Trilogy Funds Management Ltd v Sullivan [No 2] (2015) 331 ALR 185, 229 [201] (Wigney J); Australian Securities and Investments Commission v Healey (2011) 196 FCR 291, 330 [165] (Middleton J).

68 The factors mentioned by Brereton $\mathrm{J}$ in Australian Securities and Investments Commission v Maxwell (2006) 59 ACSR 373, 397 [100] and subsequent cases include 'the type of company, the provisions of its constitution [and] the size and nature of the company's business'. See also Commonwealth Bank of Australia v Friedrich (1991) 5 ACSR 115, 125 (Tadgell J). 
be unlikely to be successful. The proper taking of risk in making business decisions is entirely consistent with exercising care and diligence. ${ }^{69}$

This is further supported by the business judgment rule in section 180(2), which applies to directors who:

(a) make a judgment in good faith for a proper purpose; and

(b) do not have a material personal interest in the subject matter of the judgment; and

(c) inform themselves about the subject matter of the judgment to the extent they reasonably believe to be appropriate; and

(d) rationally believe that the judgment is in the best interests of the corporation.

In other words, in fulfilling the duty of care, directors of purpose-based companies would need to apply care, skill and diligence in seeking to achieve the purpose-based company's purposes. Such directors would not, however, necessarily breach the duty merely because these purposes were not in fact achieved. In this respect framing of constitutional provisions in terms of 'furthering' particular purposes rather than 'achieving' these purposes should be considered. ${ }^{70}$

\section{B Duty to Act in Good Faith in the Interests of the Company}

The duty to act in good faith in the interests of the company (the 'best interests rule') is the central duty of directors. It requires directors to give good faith consideration to, and direct their decisions towards, the company's interests. The duty regulates the exercise of discretion by directors ${ }^{71}-$ it is not an absolute duty to act in the interests of the company, dependent on the success of a particular transaction or course of action. ${ }^{72}$ The general law duty subsists in Australia. In addition, section 181 of the Corporations Act (which applies in addition to the general law duty $)^{73}$ provides that a director or other officer of a corporation must exercise their powers and discharge their duties '(a) in good faith in the best interests of the corporation; and (b) for a proper purpose'.

In practical terms the duty has a number of distinctive functions, namely consideration of the company's interests (which incorporates consideration of creditors' interests in some circumstances), proscribing conflicts and profits, and requiring extended disclosure of conflicted directors. ${ }^{74}$ Each of these aspects of

69 Australian Securities and Investments Commission v Lindberg (2012) 91 ACSR 640, 654 [72] (Robson J), quoted in Termite Resources NL (in liq) v Meadows (2019) 370 ALR 191, 228 [184] (White J). For further detail, see Ford, Austin \& Ramsay's Principles of Corporations Law (n 25) [8.305].

70 But see William Henderson and Jonathan Fowles, Tudor on Charities (Sweet \& Maxwell, $1^{\text {st }}$ Supplement to $10^{\text {th }}$ ed, 2018) [17-010] for a discussion of the potential elision of 'furthering' and 'achieving' in the context of charitable incorporated organisations in the UK.

71 In Re Smith and Fawcett Ltd [1942] Ch 304, 306, Lord Greene held that directors 'must exercise their discretion bona fide in what they consider - not what a court may consider - is in the interests of the company'.

72 See Australian Securities and Investments Commission v Lewski (2018) 362 ALR 286, 304 [71] (Kiefel CJ, Bell, Gageler, Keane and Edelman JJ), citing Rosemary Teele Langford, Directors' Duties:

Principles and Application (Federation Press, 2014) 61 [4.2.2].

73 See Corporations Act $\mathrm{s} 185$.

74 For demonstration of the role played by s 181 in proscribing conflicts and profits that do not fit within the narrower confines of ss 182 and 183, and conflicts and profits that relate to third parties, see, eg, Chew $v$ 
section 181 should continue to apply without modification to directors of purposebased companies. In other words the application of these aspects of the duty to directors of purpose-based companies is appropriate and does not require alteration. Moreover, specification of corporate purpose in the constitution does not obviate these requirements given that shareholder authorisation is no answer to a claim for breach of statutory duty. ${ }^{75}$

The first article addressed a particular concern as regards the application of the best interests rule to purpose-based companies, namely the fear that directors are open to litigation for breach of duty if a company's purposes are not achieved in practice. It showed that this is not the case. As mentioned above, the duty to act in good faith in the interests of the company is not an absolute duty to achieve profits or purpose but rather requires directors to exercise their discretion in good faith in the furtherance of these goals.

A related concern is that an action could be brought under section 1324 of the Corporations Act where directors do not achieve the company's purposes. Section 1324 of the Corporations Act provides that ' $[\mathrm{w}]$ here a person has engaged, is engaging or is proposing to engage in conduct that constituted, constitutes or would constitute' a contravention (or attempted contravention) of the Act, or other involvement in a contravention of the Act, the

Court may, on the application of ASIC, or of a person whose interests have been, are, or would be affected by the conduct, grant an injunction ... restraining the firstmentioned person from engaging in the conduct or requiring that person to do any act or thing.

Two points can be made in this respect. First, the section is enlivened by a breach of the Corporations Act such as a breach of a statutory directors' duty. This article argues that directors who act in good faith and with care, skill and diligence in furtherance of the purpose-based company's goals will not be in breach of duty. In other words, section 1324 is predicated on breach of a statutory duty, and directors (including directors of purpose-based companies) are not in breach of duty just because the company does not actually achieve its purposes. Second, section 1324 has been interpreted restrictively, ${ }^{76}$ particularly where damages are sought. ${ }^{77}$ This further reduces its potential scope.

The Queen (1991) 4 WAR 21, 49 (Malcolm CJ); Adler v Australian Securities and Investments Commission (2003) 179 FLR 1, 96 [439] (Giles JA); Southern Real Estate Pty Ltd v Dellow (2003) 87 SASR 1, 7-8 [23]-[25] (Debelle J); Parker Re Purcom No 34 Pty Ltd (in liq) (2010) 77 ACSR 525, 5423 [72]-[73] (Gordon J); Bell Group Ltd (in liq) v Westpac Banking Corporation [No 9] (2008) 39 WAR 1, 561-2 [4520]-[4522], 562-3 [4525] (Owen J); Re S\&D International Pty Ltd [No 4] (2010) 79 ACSR 595, 657 [284] (Robson J); Rosemary Teele Langford, Company Directors' Duties and Conflicts of Interest (Oxford University Press, 2019) 294-300 [10.08]-[10.23] ('Company Directors' Duties').

75 See above Part III(E).

76 See, eg, Messenberg v Cord Industrial Recruiters Pty Ltd (1996) 39 NSWLR 128. But see Airpeak Pty Ltd v Jetstream Aircraft Ltd (1997) 73 FCR 161; Emlen Pty Ltd v St Barbara Mines Ltd (1997) 24 ACSR 303; Macks $v$ Viscariello (2017) 130 SASR 1, 149-50 [719] (the Court).

77 See, eg, McCracken v Phoenix Constructions (Qld) Pty Ltd [2013] 2 Qd R 27; Re Colorado Products Pty Ltd (in prov liq) (2014) 101 ACSR 233, 358-60 [397]-[402] (Black J); Katy Barnett, 'A Reconsideration of s 1324(10) of the Corporations Act 2001 (Cth): Damages in Lieu of an Injunction' (2018) 36(4) Company and Securities Law Journal 370. 
Directors should make sure that they have considered the company's interests and purposes, and sought to further these interests and purposes, in order to comply with the best interests rule. A safeguard for directors is to ensure that appropriate provisions are inserted in the constitution and any shareholders' agreement to the effect that directors are to pursue specified purposes as well as profit. The appropriate framing of such constitutional provisions is addressed below.

\section{Tension between Purposes}

A particular question that has been raised in relation to the application of the best interests rule to directors of purpose-based companies is the potential tension between multiple purposes where companies adopt more than one purpose (and particularly where companies adopt purpose and profit). This has been described as a 'two masters issue'. ${ }^{78}$ This Part critically analyses these concerns, which have also been raised in relation to US benefit corporation statutes. In addition, given the importance of a constitutional provision that clearly specifies the company's purpose(s) this Part considers issues associated with the wording of such a provision. It draws on US experience and, in particular, on the work of scholars such as Reiser and Dean, Gold and Miller, and Johnson, surrounding the various US benefit corporations statutes. ${ }^{79}$ Although this scholarship concerns the issues arising from the way in which statutory provisions are drafted, it provides important insights into the drafting of constitutional provisions. It will be shown that the potential tension between different purposes is not an impediment to permitting companies to be formed for purposes other than profit or to the adoption of purpose-based governance.

Current US models have been criticised as (1) being inconsistent with the fiduciary ideal of undivided loyalty to a single person or purpose due to divided attention between loyalty to for-profit and profit-sacrificing purposes; and (2) widening discretion and weakening accountability, thus increasing agency costs and undermining public confidence in the integrity of social enterprise organisations. ${ }^{80}$ Reiser and Dean opine that current models leave leaders to determine the trade-offs between social good and profit generation ${ }^{81}$ also raising a problem of serving two masters ${ }^{82}$ and weak enforcement. ${ }^{83}$ They therefore advocate legislation stating that: ' $[\mathrm{c}$ ]orporations organized under this chapter will pursue both social good and profit for owners, but pursuit of social good will be prioritized' ${ }^{84}$ These criticisms demonstrate that problems arise even where special-purpose legislation facilitates the incorporation of purpose-based companies.

78 See Andrew S Gold and Paul B Miller, 'Fiduciary Duties in Social Enterprise' in Benjamin Means and Joseph W Yockey (eds), The Cambridge Handbook of Social Enterprise Law (Cambridge University Press, 2018) 321; Reiser and Dean, Social Enterprise Law (n 41) 19.

79 See Reiser and Dean, Social Enterprise Law (n 41); Reiser and Dean, 'The Social Enterprise Life Cycle' (n 40); Gold and Miller, 'Fiduciary Duties in Social Enterprise' (n 78); Johnson (n 43).

80 See Gold and Miller, Fiduciary Duties in Social Enterprise' (n 78) 321-2.

81 See Reiser and Dean, Social Enterprise Law (n 41) 26.

82 Ibid 19.

83 See ibid ch 3.

84 Ibid 32. 
In response to concerns in relation to divided loyalty, Gold and Miller argue that it is inaccurate to say that fiduciaries in social enterprise companies have to serve two masters. In their view fiduciaries in the public benefit corporation context have a single mandate comprising two or more purposes rather than a dual mandate. The fiduciary can be trusted to strike the right balance where the expectation of convergence or consistency between the two objectives breaks down. ${ }^{85}$ There is merit in this point given that directors are constantly exercising discretionary power in balancing and making decisions. This is partly why they are classified as fiduciaries and subject to fiduciary duties. In the context of purpose-based companies directors must exercise their discretion in considering and balancing the entity's purposes and returns to members. In addition, the relative weight of profit and purpose or of multiple purposes can be specified in a company's constitution and/or shareholders' agreement. Moreover, as outlined in Part IV above, UK authority provides that where the relative weight of the company's purposes is not specified, directors should balance these purposes. This useful guidance addresses the issue of potential tension between mandates where constitutions provide broad discretion.

A different concern is raised by Johnson, who highlights the problems of directors' duties being not only to pursue the best interests of the company (namely the pursuit of dual pecuniary and social/environmental purposes) but also to consider stakeholders. ${ }^{86}$ Johnson demonstrates that most statutes require directors to balance or consider the effects of their action (or inaction) on a cast of stakeholders, together with (as just one co-equal factor) the ability of the corporation to accomplish its general or specific public benefit. In his view the proper focus for directors should be to pursue the company's purposes, 'which are to pursue pecuniary gain for shareholders along with the identified general (or specific) public benefit for which the corporation was formed' ${ }^{87}$

Important lessons can be learnt from Johnson's analysis in terms of drafting of company objects. ${ }^{88}$ The statutes he criticises specify a list of stakeholder interests that directors are required to consider but the corporate objectives comprise only the first (shareholder interests) and last (accomplishing the general or specific public benefit) of these. For example, the Delaware statute provides:

The board of directors shall manage or direct the business and affairs of the public benefit corporation in a manner that balances the pecuniary interests of the stockholders, the best interests of those materially affected by the corporation's conduct, and the specific public benefit or public benefits identified in its certificate of incorporation. ${ }^{89}$

85 See Gold and Miller, 'Fiduciary Duties in Social Enterprise' (n 78).

86 See Johnson (n 43).

87 Ibid 343.

88 Ibid 347.

898 Del Code Ann $\S 365$ (a) (2020), quoted in ibid 348. Johnson, at ibid 347-8, also notes that the Illinois PBC provision for director conduct (805 Ill Comp Stat 40/4.01 (2013)) states:

[Directors] (1) shall consider the effects of any action upon: (A) the shareholders of the benefit corporation; (B) the employees and workforce of the benefit corporation, its subsidiaries, and its suppliers; (C) the interests of customers as beneficiaries of the general public benefit or specific public 
Johnson then gives examples from other jurisdictions that provide more certainty to directors. Directors of a Hawaii sustainable business corporation, for example, are required to consider only shareholder interests and the 'accomplishment of general and specific public benefits set forth in the sustainable business corporation's purposes' ${ }^{90}$ Johnson does, however, suggest that the statutes should state that 'directors are to consider only how their actions or inaction will advance the dual corporate purposes while doing so in a manner that directors believe, in the exercise of their good faith business judgment and in light of the corporation's purposes and circumstances, to be responsible and sustainable'. ${ }^{91}$ Johnson also points out the statutes' 'ingenious way' of linking the pursuit of a company's purpose with the best interests of the corporation. ${ }^{92}$ This is done by specifying that the pursuit of a general (or specific) public benefit is deemed to be in the best interests of the corporation. Johnson's careful analysis provides invaluable insights into how Australian purpose-based company constitutional provisions could be drafted.

\section{Implications}

The points made by each of these commentators have significant merit. Arguably those adopting a purpose-based company form should ideally be able to choose which model they prefer based on the amount of discretion thought desirable and which investors are being sought. For example, where specific types of investment (whether philanthropic or for-profit) are a priority and it is therefore (or independently) thought more desirable to restrict directors' discretion by specifying an overriding priority then the more restrictive model propounded by Reiser and Dean may be preferable. By contrast, where greater directorial discretion is thought appropriate then a broader model may be preferred.

As outlined by Nehme and Martin, one option is to provide that the board is acting in the best interests of the company when it is (a) directly delivering on the company's stated purpose and (b) when it considers a number of factors. ${ }^{93}$ The constitution could also provide that 'the Board is not required to regard any interest, or the interests of any particular group affected by a decision made by the Board, as a dominant or controlling interest or factor' ${ }^{94}$ On the other hand, a

benefit purposes of the benefit corporation; (D) community and social considerations, including those of each community in which offices or facilities of the benefit corporation, its subsidiaries or its suppliers are located; (E) the local and global environment; (F) the short-term and long-term interests of the benefit corporation, including benefits that may accrue to the benefit corporation from its long-term plans and the possibility that these interests may be best served by the continued independence of the benefit corporation; and $(\mathrm{G})$ the ability of the benefit corporation to accomplish its general public benefit purpose and any specific benefit purpose.

90 Haw Rev Stat § 420D-6(a)(1)(b) (2018), cited in Johnson (n 43) 348.

91 Johnson (n 43) 352. Likewise Gold and Miller note (based on B Lab Model Legislation (n 41)) that directors can be required to take into account the interests of shareholders and those of certain stakeholders (such as employees and customers) in addition to public interest considerations when deciding which course of action is in the company's best interests: see Gold and Miller, 'Fiduciary Duties in Social Enterprise' (n 78) 328.

92 Johnson (n 43) 344

93 Nehme and Martin (n 2) 139, quoting Constitution, AbilityMate (at February 2019) art 2.2.

94 Nehme and Martin (n 2) 139. An example of a broader constitutional provision is as follows: 
constitutional provision could specifically require one interest or purpose to be given priority. ${ }^{55}$ Careful attention to drafting appropriate constitutional provisions is therefore very important.

\section{Duty to Act for Proper Purposes}

The duty to act for proper purposes requires directors to exercise their powers for the purposes for which they were expressly or impliedly conferred. Section 181(1)(b) of the Corporations Act (which applies in addition to the general law duty ${ }^{96}$ provides that a director or other officer of a corporation must exercise their powers and discharge their duties for a proper purpose. Although overlapping with the duty to act in good faith in the interests of the company, the duties are distinct. ${ }^{97}$

Where there is only one purpose motivating directors, courts generally apply the two-step test in Howard Smith Ltd v Ampol Petroleum Ltd, ${ }^{98}$ which involves determining the purposes for which the relevant power was exercised (as a matter of fact) and whether those purposes were within the range of permissible purposes (identified by law). Two different tests have been employed where directors' purposes are mixed. ${ }^{99}$ These tests are at times combined so that, in order to

1. [Purpose of the Company]: The purpose of the Company is to operate as a profitable business while at the same time fulfilling the mission in clause 2. Subject to compliance with [Australian] law, the Directors have absolute discretion in how they allocate the use of all that the Company has.

2. [Mission] The Company is a social enterprise and operates to create a material positive impact on society and the environment through its operation as a business. The Mission of the Company is to [insert Mission]. It will outwork this social purpose through encouraging the following three pathways: [Insert specific principles such as encouraging environmentally sustainable practices, encouraging healthier eating and lifestyle choices]

3. [Considerations] In acting in the best interests of the Company to fulfil the Mission, the Directors will consider the effects that any action, or inaction, will have on the following stakeholders:

- $\quad$ the Shareholders;

- the employees;

- $\quad$ the suppliers;

- $\quad$ its customers;

- $\quad$ the community and society in which it operates;

- $\quad$ the local and global environment; and

- $\quad$ the short and long term future and interests of the Company.

The constitution also contains a clause governing the use of profits. Thanks to Steven Moe of Parry Field Lawyers for this example.

95 The model proposed by B Lab Australia has a list of factors to which directors must have regard and then states that directors need not give priority to a particular one of these interests over any other matter unless the benefit company has stated in its constitution that the directors or other officers must give priority to certain matters related to the accomplishment of its general public benefit purpose or any specific public benefit purpose in its constitution: see B Lab Australia and New Zealand (n 6) Attachment $\mathrm{D}, 5[4.5]$.

96 See Corporations Act s 185.

97 See Eclairs Group Ltd v JKX Oil \& Gas plc [2016] 3 All ER 641, 659 [36] (Lord Sumption).

98 [1974] AC 821, 835 (Lord Wilberforce).

99 The first test ascertains the 'substantial object the accomplishment of which formed the real ground of the board's action': see Mills v Mills (1938) 60 CLR 150, 186 (Dixon J). The second test asks whether the impermissible purpose (whether the dominant purpose or but one of a number of significantly contributing causes) was 'causative in the sense that, but for its presence, "the [relevant] power would not 
establish a breach, it must be shown that the director's substantial purpose was improper and that, but for that improper purpose, the director would not have exercised the power. ${ }^{100}$

The duty to act for proper purposes can be applied to directors of purposebased companies without modification. In fact, a determination of the purposes for which directors should be acting will be more straightforward in relation to purpose-based companies than in relation to other companies in some cases. As stated by Austin and Ramsay, ${ }^{101}$ '[i]n the absence of guidance in the constitution the court has to make inferences - on the basis, for example, of the type of company, its activities and its particular constitutional structure'. The purposes clause of a purpose-based company is therefore pertinent in the application of the proper purposes rule.

A number of cases applying this duty concern directors whose purpose was self-interest. Directors of purpose-based companies who are motivated by selfinterest will breach the proper purposes rule. At the same time, the application of the proper purposes rule in circumstances where directors are motivated by purposes other than those specified in the purpose-based company's constitution may give rise to interesting questions. For example, if certain purposes are specified but a director is motivated by a different purpose (not related to selfinterest) then the director may breach the proper purposes rule unless the company also has a broader purpose of public benefit and the purpose that motivated the director can be seen as consistent with that. As mentioned above, if the purposebased company has more than one non-prioritised purpose, directors should exercise discretion in balancing these purposes. ${ }^{102}$

\section{Duties to Avoid Conflicts of Interest and Profits from Position}

The duties to avoid unauthorised conflicts of interest and profits from position are core fiduciary duties of directors. ${ }^{103}$ The duty to avoid conflicts has two subsets, namely (1) conflicts between the company's interests (or the director's duties to the company) and the personal interests of the director; and (2) conflicts between the company's interests (or the director's duties to the company) and the director's other duties. Breach of duty depends on establishment of a 'real sensible possibility of conflict'. ${ }^{104}$ Proof of breach of the duty to avoid profits from position requires

have been exercised"': see Whitehouse v Carlton Hotel Pty Ltd (1987) 162 CLR 285, 294 (Mason, Deane and Dawson JJ). The difference between the tests is, however, more theoretical than real because, even under the second test, the improper purpose must be a significantly contributing cause so that an improper purpose that was subordinate to a proper purpose that caused the action would be acceptable: see Elizabeth Boros and John Duns, Corporate Law ( $3^{\text {rd }}$ ed, Oxford University Press, 2013) 229 [11.5.3(b)].

100 See, eg, Haselhurst $v$ Wright (1991) 4 ACSR 527; Kokotovich Constructions Pty Ltd v Wallington (1995) 17 ACSR 478; Permanent Building Society (in liq) v Wheeler (1994) 11 WAR 187.

101 Ford, Austin \& Ramsay's Principles of Corporations Law (n 25) [8.210].

102 See above Part IV(B)(2)(b).

103 See, eg, Chan v Zacharia (1984) 154 CLR 178, 198-9 (Deane J).

104 Boardman v Phipps [1967] 2 AC 46, 124 (Lord Upjohn). 
establishment of a nexus between the relevant profit and the director's position. The duty is particularly important as concerns corporate opportunities. ${ }^{105}$

The statutory duties in the Corporations Act that correspond to the fiduciary duties to avoid conflicts and profits are expressed somewhat differently to the original fiduciary duties. Sections 191 and 195 require disclosure of material personal interests and, in the case of public companies, restrictions on participation in related decision-making. Sections 182 and 183 prohibit improper use of position and of information from position. Chapter 2E regulates related party transactions.

The application of the general law and statutory conflicts and profits duties to directors of purpose-based companies is appropriate and does not require modification. These duties aim to discourage self-seeking action (and action benefiting third parties), which should also be discouraged as concerns directors of purpose-based companies. A company's purposes should also be borne in mind in the application of the conflicts rule given that that rule proscribes conflicts between the director's personal interests (or duties) and the company's interests (or the director's duty to act in good faith in the interests of the company). Where the company is purpose-based the entity's purposes are therefore fundamental to a determination of the company's interests..$^{106}$

Where companies are purpose-based, Gold and Miller suggest that an additional element comes into play in the application of the conflicts rule. ${ }^{107}$ They argue that fiduciaries are required 'to avoid undertaking a new mandate if their pursuit of the purposes underlying it may undermine their uninhibited pursuit of the purposes stipulated for an existing mandate'. ${ }^{108}$ An example would be a director of a benefit corporation taking on a directorship of a for-profit company that has conflicting interests or that causes environmental harm. As concerns Australian law, Gold and Miller are correct that such a situation may constitute a conflict of duties and therefore engage the conflicts rule. At the same time it could also potentially give rise to a breach of the duty to act in good faith in the interests of the company.

It should be noted that where directors are required to balance multiple purposes (as specified in a purpose-based company's constitution) this does not constitute a conflict of interest or of duties but rather the exercise of discretion in acting in good faith in the interests of the company.

105 See, eg, Streeter v Western Areas Exploration Pty Ltd [No 2] (2011) 278 ALR 291; Links Golf Tasmania Pty Ltd v Sattler (2012) 213 FCR 1. For critical analysis of the duties to avoid conflicts of interest and profits from position, see Langford, Company Directors' Duties (n 74) ch 4.

106 Australian Government, Australian Charities and Not-for-profits Commission, 'Managing Conflicts of Interest: A Guide for Charity Board Members' (Guide, November 2015) 7.

107 See Gold and Miller, 'Fiduciary Duties in Social Enterprise' (n 78) 340.

108 Paul B Miller and Andrew S Gold, 'Fiduciary Governance' (2015) 57(2) William and Mary Law Review $513,563$. 


\section{OTHER ISSUES}

This article has argued that Australian law allows the incorporation of purposebased companies without legislative change. However, a number of disadvantages to not having special-purpose legislative facilitation of purpose-based companies have been raised. These include standing and enforcement, concerns surrounding companies departing from their purposes, and signalling. This Part briefly raises and comments on some of these issues. It demonstrates that a number of mechanisms (including regular disclosure, provisions in company constitutions and shareholders' agreements, B Corp certification and the oppression remedy) go some way to meeting the practical concerns that are expressed in relation to purpose-based companies. Despite the potential advantages of special-purpose legislation, critical analysis of US benefit corporation legislation also demonstrates the potential disadvantages of such legislation and the lessons that can therefore be learnt if special-purpose legislation is ever enacted in Australia.

\section{A Standing and Enforceability}

The first set of key issues is standing and enforcement. In this respect, revitalisation of the law to enable purpose-based companies does not necessarily require changes in standing. Directors of purpose-based companies remain, under the model outlined above, accountable to the company and therefore ultimately to shareholders. In addition, Australia has a unique regulatory regime, which includes a corporate regulator, the Australian Securities and Investments Commission ('ASIC'), that has standing to bring action to enforce the Corporations Act, including directors' duties. In fact many directors' duties actions are brought by ASIC. ${ }^{109}$

Practical measures that enhance transparency and enforcement are disclosure and reporting. ${ }^{110}$ Disclosure and reporting play a key part in the regulation of all companies. Reporting is in fact taking on an increasingly significant role to the point that some commentators view reporting requirements as an influential way to make companies more socially responsible and to adjust corporate behaviour. ${ }^{11}$ Disclosure has the added advantage of allowing investors to choose which type of company to invest in. Increased disclosure and additional reporting are measures that could be considered in the facilitation of purpose-based companies.

109 See, eg, Ian M Ramsay and Benjamin B Saunders, 'An Analysis of the Enforcement of the Statutory Duty of Care by ASIC' (2019) 36(6) Company and Securities Law Journal 497, 498.

110 See Reiser and Dean, Social Enterprise Law (n 41) 36-7. Reiser and Dean also advocate the enabling of shareholder litigation by providing for payment of shareholder legal fees: see Reiser and Dean, Social Enterprise Law (n 41) 46. The Impact Initiative Report (n 8) proposes that each impact company would be required to prepare and publish an annual report that outlines how it has performed in achieving its impact mission: at 31 .

111 See Jean Jacques du Plessis, 'Disclosure of Non-Financial Information: A Powerful Corporate Governance Tool' (2016) 34(1) Companies and Securities Law Journal 69; Jean Jacques du Plessis, 'Shareholder Primacy and Other Stakeholder Interests' (2016) 34(3) Company and Securities Law Journal 238. 
It would be possible to expand standing in relation to purpose-based companies. ${ }^{112}$ Thus in purpose-based companies individuals and bodies other than, or as well as, shareholders and the regulator could be tasked with enforcement. ${ }^{13}$ This would require legislative change and close consideration of which stakeholders should have standing. ${ }^{114}$ The experience of overseas jurisdictions is again instructive. In particular, the criticisms of US benefit proceedings, outlined in Part IV above, should be carefully considered. Any legislative facilitation of enforcement proceedings would also need to ensure a careful balance between accountability and not discouraging people from taking up directorships of purpose-based companies. ${ }^{115}$

\section{B Departure from Purposes}

A significant concern of founders of purpose-based companies is to make sure that the company's purpose will continue in the event of any change in control and that profits will not be inappropriately extracted. ${ }^{116}$ In the case of CICs extra mechanisms are put in place, such as asset locks. However, asset locks have in turn been criticised. ${ }^{117}$ Other ways of attaining protection in the absence of specialpurpose legislation are provisions in the company's constitution and shareholders' agreements, and obtaining B Corp certification. ${ }^{118}$ These measures make it more difficult to change the company's purpose and direction if it is taken over. In addition, directors may breach their duties to act with care, skill and diligence and in good faith in the interests of the company if they cause the company to depart from its purposes. ${ }^{119}$

112 Gold and Miller suggest that duties be enforced by persons entrusted with the responsibility of protecting the purposes of the underlying organisation or institution: see Gold and Miller, 'Fiduciary Duties in Social Enterprise' (n 78) 324.

113 An example is Charities Act 2011 (UK) s 115. Section 115(1) allows '[c]harity proceedings' to be taken 'with reference to a charity' by '(a) the charity, (b) any of the charity trustees, (c) any person interested in the charity, or (d) if it is a local charity, any two or more inhabitants of the area of the charity'. Such proceedings do, however, have to be authorised by the Charity Commission: see at s 115(2). See also at ss 115(3)-(7).

114 B Lab proposes that standing to bring benefit enforcement proceedings be conferred on 'a member or group of members with at least $5 \%$ of the votes that may be cast at a general meeting of the company' or 'an officer of the company' [in addition to ASIC]: see B Lab Australia and New Zealand (n 6) Attachment C, 3 [2.4].

115 The application of section 1324 of the Corporations Act was analysed above in Part V(B).

116 See Boeger (n 3) 128-9. This is a criticism of the US benefit corporation statutes: see Reiser and Dean, Social Enterprise Law (n 41) ch 3.

117 See above Part IV(B)(2). See also Gold and Miller, 'Fiduciary Duties in Social Enterprise' (n 78 ) 337.

118 But see Impact Initiative Report (n 8) 12-21.

119 For discussion of these duties see above Parts V(A), (B). See also Ford, Austin \& Ramsay's Principles of Corporations Law (n 25) [12.190]; Sue Woodward, “Ultra Vires” Oversimplified: Changes to Company Powers under the Second Corporate Law Simplification Bill' (1997) 15(3) Company and Securities Law Journal 162. This may in turn enliven s 1324, although note the limitations outlined above in Part V(B). 
A remedy that appears to be overlooked in this debate is the oppression remedy in sections $232-3$ of the Corporations Act. ${ }^{120}$ Section 232 empowers the court to make an order under section 233 if:

(a) the conduct of the company's affairs; or

(b) an actual or proposed act or omission by or on behalf of a company; or

(c) a resolution, or proposed resolution, of members or a class of members of a company is either:

(d) contrary to the interests of the members as a whole; or

(e) oppressive to, unfairly prejudicial to, or unfairly discriminatory against, a member or members whether in that capacity or in any other capacity.

The advantages of the oppression action are that (1) unlike the statutory derivative action, shareholders do not have to apply to the court to gain standing and (2) there is significant remedial flexibility. Section 233(1) gives the court broad discretion to make such order or orders as it thinks appropriate, ${ }^{121}$ and courts have shown a willingness to exercise this discretion. ${ }^{122}$

Where a company is established with a clear purpose, a departure from that purpose may be found to be contrary to the interests of the members as a whole or oppressive to a member who objects to that departure. For example, in Szencorp Pty Ltd v Clean Energy Council Ltd, Goldberg J held that

[a]n example [of conduct contrary to the interests of the company's members as a whole] may be found where a company is formed for the purpose of undertaking particular activities but the directors and management disregard those activities and direct the company into different commercial areas. ${ }^{123}$

Courts have recognised that members have an interest in entities' affairs being conducted in accordance with the constitution and that non-compliance with the constitution may constitute action contrary to the interests of the members as a whole for the purpose of oppression actions. ${ }^{124}$

120 Section 234 confers standing, inter alia, upon members (including 'a person who has ceased to be a member of the company if the application relates to the circumstances in which they ceased to be a member'): at s 234(c); and 'a person whom ASIC thinks appropriate having regard to investigations it is conducting or has conducted into: (i) the company's affairs; or (ii) matters connected with the company's affairs': at s 234(e).

121 Examples given in section 233(1) include: an order that the company be wound up; an order that the company's constitution be modified or repealed; an order for regulating the conduct of the affairs of the company in the future; an order for the purchase of a member's shares by other members or by the company; an order directing the company to institute, defend, or discontinue specified proceedings, or authorising a member of the company to institute, prosecute, defend, or discontinue specified proceedings in the name and on behalf of the company; an order appointing a receiver (or receiver and manager) of property of the company; an order requiring a person to do a specified act or thing; and an order restraining a person from engaging in specified conduct or from doing a specified act.

122 See, eg, Jenkins v Enterprise Gold Mines NL (1992) 6 ACSR 539; Fexuto Pty Ltd v Bosnjak Holdings Pty Ltd (2001) 37 ACSR 672; LPD Holdings (Aust) Pty Ltd v Phillips (2013) 281 FLR 227.

123 (2009) 69 ACSR 365, 379 [59].

124 See, eg, Popovic v Tanasijevic [No 5] (2000) 34 ACSR 1, 71 [505] (Olsson J); Bull v Australian Quarter Horse Association [2014] NSWSC 1665, [325] (Hallen J); Pettit v South Australian Harness Racing Club Inc (2006) 95 SASR 543, 548-50 [26] (White J); Power v Ekstein (2010) 77 ACSR 302, 322 [68] (Austin J). See also Woodward (n 119) 164. Note also that breach of directors' duties may constitute oppression on the basis that it is contrary to the interests of the members as a whole-members can bring an oppression action based on breach of directors' duties without seeking leave to bring a statutory 
An early example is the case of Re Tivoli Freeholds Ltd ('Re Tivoli') in which Menhennitt $\mathrm{J}$ stated that

it may be just and equitable to wind a company up if the company engages in acts which are entirely outside what can fairly be regarded as having been within the general intention and common understanding of the members when they became members. ${ }^{125}$

His Honour noted that this concept is not confined to certain types of companies. $^{126}$ In Re Tivoli winding up was justified on the basis that the main objects of the company were to carry on an entertainment business and associated activities but the company then became engaged in corporate raiding. ${ }^{127}$ The case was based on winding up under the predecessor to section 461(1)(k) of the Corporations Act, but the doctrine may also form the basis of oppression actions, particularly now that the oppression action has been rendered less restrictive. ${ }^{128}$ This ground for an oppression action may be framed in terms of departure from 'legitimate' or 'reasonable' expectations or from the common intention and understanding of the members, or in terms of 'failure of substratum' ${ }^{129}$ The latter may also ground a claim for winding up on the just and equitable ground.

The application of this principle is all the clearer in relation to purpose-based companies because such companies do specify purposes. This means that it is more straightforward to ascertain the common understanding of the members. Although other documents may be consulted in determining the common understanding of the members, in Re Tivoli, Menhennitt $\mathrm{J}$ stated that 'the prime source for ascertaining the general intention and common understanding of the members is the company's memorandum of association which among other things states its objects'. ${ }^{130}$ Where, as advocated in this article, companies specify purposes in their constitution, there is a strong basis for demonstrating the common understanding

derivative action under s 237: see, eg, Lukaszewicz v Polish Club Ltd (2019) 370 ALR 698, 779 [271] (Black J).

125 [1972] VR 445, 468 ('Re Tivoli').

126 Ibid 469. His Honour drew on the following justification:

That, I take it, means that, if a shareholder has invested his money in the shares of the company on the footing that it is going to carry out some particular object, he cannot be forced against his will by the votes of his fellow shareholders to continue to adventure his money on some quite different project or speculation.

at ibid 470, quoting Re Eastern Telegraph Co Ltd [1947] 2 All ER 104 (Jenkins J).

127 This doctrine was also drawn upon in the more recent case of Re Hillsea Pty Ltd [2019] NSWSC 1152, [109]-[110] (Black J) (upheld on appeal in Hillsea Pty Ltd v Joseph [2020] NSWCA 55) in which it was found that the members' common intention was that the company be established to undertake a clothing manufacture business and property development but that the company was subsequently used to confer benefits on some family members.

128 See Companies and Securities Legislation (Miscellaneous Amendments) Act 1983 (Cth) s 89. As pointed out by Austin and Ramsay, Re Tivoli was decided when the statutory remedy short of winding up was available only for 'oppression', but now the remedy incorporates the concept of unfair prejudice. The circumstances in Re Tivoli would now constitute unfair prejudice under s 232: see Ford, Austin \& Ramsay's Principles of Corporations Law (n 25) [10.450.21]. See also at [10.386].

129 For discussion, see Ford, Austin \& Ramsay's Principles of Corporations Law (n 25) [10.450.15], [10.400.12].

130 [1972] VR 445, 471. 
of the members. This provides a good foundation for an oppression action if a company subsequently departs from pursuing its original purpose(s) or changes character in a significant way.

A mechanism that is raised in this context is the potential ability of members to enforce the terms of the constitution based on section 140(1) of the Corporations Act. Section 140(1) provides that a company's constitution has effect as a contract between, inter alia, the company and each member and between the company and each director 'under which each person agrees to observe and perform the constitution and rules so far as they apply to that person'. A literal reading of that section would suggest that a member could bring an action based on section 140(1) where a company with clear purposes changes direction and departs from those purposes. The application and operation of section 140 are, however, in many ways uncertain. For example it is not clear that the rights of members in their capacity as members extend to the right to have the company's affairs conducted in accordance with the constitution. ${ }^{131}$ In addition remedies are limited. ${ }^{132}$ Given these uncertainties, entry into a shareholders' agreement, where possible, is therefore beneficial. More importantly, the practical relevance of actions based on section 140 has decreased due to the availability of the oppression remedy. ${ }^{133}$ As mentioned above, departure from the purposes in an entity's constitution may ground an oppression action.

\section{Signalling}

One of the advantages of a special-purpose legislative structure is that it signals a purpose-based company's purpose and nature. Klettner argues that 'if purpose is just as important as profit for an organisation this needs to ... be signalled to external stakeholders'. ${ }^{134}$ The Impact Initiative Report includes 'the lack of ability to signal and protect the primacy of impact for [social enterprise]' as one of the two 'most resounding disadvantages of the existing legal structures'.135 Practitioners and commentators, however, opine that this can also be achieved by seeking B Corp certification ${ }^{136}$ and by astute marketing.

131 See, eg, Magill v Santina Pty Ltd (1983) 1 NSWLR 517; Norths Ltd v McCaughan Dyson Capel Cure Ltd (1988) 12 ACLR 739; Stanham v National Trust of Australia (NSW) (1989) 15 ACLR 87, 90 (Young J). For discussion, see Ford, Austin \& Ramsay's Principles of Corporations Law (n 25) [6.120].

132 As to declarations and injunctions: see, eg, Wood v Odessa Waterworks Company (1889) 42 Ch D 636; Grant v John Grant \& Sons Pty Ltd (1950) 82 CLR 1; Shaw Stockbroking Ltd v Australian Stock Exchange Ltd (1998) 26 ACSR 702. As to rectification: see, eg, Scott v Frank F Scott (London) Ltd [1940] 1 Ch 794; Wambo Coal Pty Ltd v Sumiseki Materials Co Ltd (2014) 88 NSWLR 689. As to damages: see, eg, Houldsworth $v$ City of Glasgow Bank (1880) 5 App Cas 317; Ardlethan Options Ltd $v$ Easdown (1915) 20 CLR 285; Dungowan Manly Pty Ltd v McLaughlin (2012) 90 ACSR 62.

135 See Impact Initiative Report (n 8) 30. The Report identifies the other key disadvantage as funding. See Klettner (n 4) 348. See also Boeger (n 3) 129. 


\section{CONCLUSION}

Against background analysis of pertinent aspects of the development of Australian corporations law, this article has critically analysed challenging issues that arise in the application of directors' duties in the context of purpose-based companies. Particular focus has been placed on the application of such duties where a purpose-based company has multiple purposes and the correlative insights that can be drawn for the drafting of purpose-based company constitutional provisions. It has also briefly discussed other issues raised in relation to purposebased companies in the absence of special-purpose legislation, such as enforcement, signalling and departure from purposes. Jurisprudence arising from the experience of overseas jurisdictions is a rich source of inspiration and guidance in these respects given that these jurisdictions have confronted multiple issues in facilitating purpose-based companies.

This analysis demonstrates that revitalisation of Australian corporations law to allow purpose-based companies is perfectly feasible. Indeed it is opportune. By recognising the ability of companies to adopt purposes and for directors' duties to be centred in, and animated by, those purposes, corporations law can be attuned to practical and conceptual developments in the corporate sphere and more broadly. Such revitalisation does not require a fundamental shift, particularly given the malleability of directors' duties. Indeed, given that the origins of the corporate form were connected with public ends, this evolution of the corporate form, and the attendant adaption of directors' duties, are a natural adaptation rather than a radical reformulation. 


\section{University Library}

\section{- M M N E R VA A gateway to Melbourne's research publications}

Minerva Access is the Institutional Repository of The University of Melbourne

Author/s:

Langford, R

Title:

Use of the Corporate Form for Public Benefit - Revitalisation of Australian Corporations Law

Date:

2020

Citation:

Langford, R. (2020). Use of the Corporate Form for Public Benefit - Revitalisation of Australian Corporations Law. University of New South Wales Law Journal, 43 (3), pp.977-1005. https://doi.org/10.53637/eryj2395.

Persistent Link:

http://hdl.handle.net/11343/243030 